УДК 631.527.633.3

(C) 2012

\author{
Колісник I. В., кандидат сільськогосподарських наук, \\ Барилко М. Г., науковий співробітник \\ ПДСГДС ім. М. І. Вавилова ІС і АПВ НААН
}

Колісник А. В., кандидат біологічних наук

Полтавський інститут МАУП

\title{
АГРОЕКОЛОГІЧНІ АСПЕКТИ СЕЛЕКЦИЙНОГО ВИКОРИСТАННЯ ЗРАЗКІВ ВИКИ ЯРОЇ КОЛЕКЦІЇ ПДСГДС ім. М. І. ВАВИЛОВА
}

\author{
Рецензент - доктор сільськогосподарських наук, професор В. М. Тищенко
}

Викладені результати багаторічної роботи із всебічного вивчення селекиійної та агроекологічної иінності зразків колекиії вики ярої Полтавської державної сільськогосподарської дослідної станиії ім. М. І. Вавилова; виділені джерела господарсько цінних ознак, попередньо з'ясовано перспективи використання взаємодії макро- і мікросимбіонтів, окреслено иляхи можливого використання як самої культури, так і окремих сортів вітчизняної селекції у створенні елементів системи біологічного землеробства з метою покращчання азотного жсивлення рослин та захисту їх кореневої системи від негативного впливу трунтових патогенів.

Ключові слова: колекція, генофонд, селекиія, вика яра, зразки, азотфіксачія, біологічне землеробство.

Постановка проблеми. Екологізація аграрного сектора та перспективи розвитку органічного землеробства в Україні, безумовно, вимагатимуть включення до системи землеробства альтернативних джерел азоту, з-поміж яких бобові культури займають виняткове положення. Найбільший потенціал, як доведено окремими авторами, $є$ у люцерни, але його реалізація у багаторічної культури пов'язана 3 певними проблемами [6]. Тому виникає необхідність більш глибокого вивчення інших бобових кормових культур, особливо ярового типу розвитку, що можуть органічно включатися до сівозміни. Серед таких найбільшу цікавість може представляти саме вика яра (Vicia sativa), азотфіксуючий потенціал якої можна збільшити шляхом використання інокулянтів.

Бобові культури й є основним об'єктом селекційної роботи наукового колективу Полтавської державної сільськогосподарської дослідної станції ім. М. І. Вавилова впродовж досить тривалого часу (понад 80 років), який працює як над створенням нових сортів кормових культур, так i ï впровадженням у виробництво. Серед них - i вика яра (горошок посівний), до можливостей та перспектив якої останнім часом спостерігається посилена цікавість агровиробників.

Аналіз останніх досліджень і публікацій, у яких започатковано розв'язання проблеми. Вика яра - цінна кормова культура, що здатна забезпечувати один із найвищих серед однорічних кормових культур збір сухої речовини, кормових одиниць та сирого протеїну 3 одиниці площі. Вона вирізняється швидким нарощенням вегетативної маси, що дає можливість досить рано використовувати іiї на корм. Максимальний вихід сирого протеїну зафіксовано в період наливу зерна [1]. У зоні сірих лісових грунтів саме в зеленій масі вики зафіксовано найбільший серед однорічних бобових кормових культур вихід сухої речовини та збір сирого протеїну [7].

Протягом усього періоду ведення селекційної роботи з викою ярою селекціонерами ПДСГДС досить широко використовувалися доступні резерви наявного генофонду культури. Повно й ефективно використовувати генетичне різноманіття рослин у селекції, наукових та інших програмах дає змогу саме формування базових, ознакових, спеціальних, робочих, навчальних та інших колекцій на основі всебічного вивчення зразків генофонду і виділення зразків-еталонів рівнів прояву господарсько цінних ознак [2].

Мета та методика проведення досліджень. Дослідження мали на меті вивчення можливостей (одночасно 3 підвищенням азотфіксуючої здатності) захисту кореневої системи вики від фузаріозних гнилей $[3,4,5]$, а також дії екологічних факторів, що впливають на цей процес. У дослідах використовувалися штами бульбочкових бактерій із колекції Кримського ФІСГМ. Для визначення впливу різних чинників на прояв взаємодії макро- і мікросимбіонтів використовувалися 2-3-факторні моделі (сорт - штам - умови зволоження).

Використання зразків колекції, передусім як вихідного матеріалу для селекції, продиктовано 
необхідністю залучення широкого спектру мінливості ознак. Результативність селекційної роботи в значній мірі залежить від підбору вихідного матеріалу, вдалого поєднання джерел необхідних ознак, використання форм різного географічного походження, що, в свою чергу, викликає необхідність детального вивчення колекційного матеріалу культури 3 метою виділення перспективних для селекції зразків за важливими господарсько цінними ознаками.

Колекція вики ярої (горошку посівного) Полтавської державної сільськогосподарської дослідної станції ім. М. І. Вавилова налічує 90 зразків, що належать до виду Vicia sativa L. і походять із 13-ти країн світу, зокрема: з України - 35, Росії 31 , Білорусі - 4, Болгарії - 4, Угорщини - 3, Португалії - 3, Югославії - 3, Італії - 2, Швеції 1 , Туреччини -1 , Чехії - 1 , Словаччини -1 , Сербії - 1. Зразки вітчизняного походження створені в ПІАПВ (ПДСГДС) ім. М. І. Вавилова - 12, на Білоцерківській ДСС - 11, Вінницькій ДС - 10, Подільській ДС - 1, Красноградській ДС - 1 .

Усі зразки даної ознакової колекції протягом шести років (2005-2011) оцінювалися в польо- вих умовах по 15-ти господарськи цінних ознаках. Інформація про всі зразки даної колекції занесена до паспортної бази даних Інформаційної системи «Генофонд рослин».

Вивчення проводилося в грунтово-кліматичних умовах Лівобережного Лісостепу України, на Полтавському відділку ПДСГДС імені M. I. Вавилова. Досліди закладалися на полях селекційної сівозміни, розміщеної на темносірих опідзолених за механічним складом грунтах, що характеризуються такими агрохімічними показниками орного шару на глибині 0-30 см: гідролітична кислотність - 1,9-3,3 мг екв. на 100 г грунту; вміст гумусу - 2,44-3,46\%; $\mathrm{pH}$ сольової витяжки - 5,8-5,9; рухомих форм фосфору - 13-21 мг на 100 г грунту; легко гідролізованого азоту - 4,42-7,94 мг на 100 г грунту; обмінного калію - 16-20 мг на 100 г грунту; сума ввібраних основ - 21-30 мг на 100 г грунту.

Результати досліджень. За результатами багаторічного вивчення зразків колекції вики ярої було виділено джерела цінних господарських ознак.

\section{1. Джерела окремих цінних господарських ознак колекції вики ярої}

\begin{tabular}{|c|c|c|c|}
\hline \multirow[t]{2}{*}{ Ознака } & \multicolumn{3}{|c|}{ Зразок } \\
\hline & № нац. каталога & походження & назва \\
\hline 1 & 2 & 3 & 4 \\
\hline Облистяність, шт. & $\begin{array}{c}\text { UD0900045 } \\
\text { UD0900068 } \\
\text { UD0900051UD090 } \\
0053\end{array}$ & $\begin{array}{c}\text { Росія } \\
\text { Угорщина } \\
\text { Болгарія } \\
\text { Болгарія }\end{array}$ & M-1 \\
\hline Висота рослини, см & $\begin{array}{l}\text { UD0900051 } \\
\text { UD0900023 } \\
\text { UD0900318 } \\
\text { UD0900306 } \\
\text { UD0900547 }\end{array}$ & $\begin{array}{c}\text { Болгарія } \\
\text { Росія } \\
\text { Україна } \\
\text { Україна } \\
\text { Україна }\end{array}$ & $\begin{array}{c}\text { Дробинка } \\
\text { Мутант широколистий } \\
\text { Наталі } \\
19168\end{array}$ \\
\hline $\begin{array}{c}\text { Висота прикріплення } \\
\text { нижнього боба, см }\end{array}$ & $\begin{array}{l}\text { UD0900161 } \\
\text { UD0900163 } \\
\text { UD0900051 } \\
\text { UD0900055 } \\
\text { UD0900023 } \\
\text { UD0900434 } \\
\text { UD0900218 } \\
\text { UD0900070 } \\
\text { UD0900215 } \\
\text { UD0900546 } \\
\text { UD0900306 }\end{array}$ & $\begin{array}{c}\text { Швеція } \\
\text { Росія } \\
\text { Болгарія } \\
\text { Болгарія } \\
\text { Росія } \\
\text { Білорусь } \\
\text { Чехія } \\
\text { Україна } \\
\text { Словаччина } \\
\text { Україна } \\
\text { Україна }\end{array}$ & $\begin{array}{c}\text { Дробинка } \\
\text { Мила } \\
\text { Євена } \\
\text { Гібридна } 2 \\
\text { Торlesa } \\
\text { 18333-2-2 } \\
\text { Наталі }\end{array}$ \\
\hline
\end{tabular}




\begin{tabular}{|c|c|c|c|}
\hline & & & Продовження табл. 1 \\
\hline 1 & 2 & 3 & 4 \\
\hline Кількість бобів & UD0900051 & Болгарія & \\
\hline на 1 рослину, шт. & UD0900068 & Угорщина & M-1 \\
\hline & UD0900452 & Україна & Добір 332/2 \\
\hline & UD0900072 & Україна & Гібридна 13 \\
\hline & UD0900308 & Росія & Biopa \\
\hline & UD0900167 & Україна & Ізида \\
\hline & UD0900218 & Угорщина & Свена \\
\hline Кількість насіння & UD0900045 & Росія & \\
\hline на 1 рослину, шт. & UD0900046 & Туреччина & \\
\hline & UD0900051 & Болгарія & \\
\hline & UD0900056 & Болгарія & \\
\hline & UD0900067 & Угорщина & SZ-3 \\
\hline & UD0900218 & Чехія & Євена \\
\hline & UD0900452 & Україна & Добір 332/2 \\
\hline & UD0900072 & Україна & Гібридна 13 \\
\hline & UD0900003 & Україна & Багатоплідна \\
\hline & UD0900167 & Україна & Ізида \\
\hline Маса насіння & UD0900168 & Угорщина & M-1 \\
\hline на 1 рослину, г & UD0900051 & Болгарія & \\
\hline & UD0900218 & Чехія & Євена \\
\hline & UD0900167 & Україна & Ізида \\
\hline Маса 1000 насінин, г & UD0900161 & Швеція & \\
\hline & UD0900055 & Болгарія & \\
\hline & UD0900028 & Україна & Білоцерківська 34 \\
\hline & UD0900434 & Білорусь & Мила \\
\hline & UD0900168 & Україна & Білоцерківська 10 \\
\hline & UD0900547 & Україна & 19168 \\
\hline Високий вміст сирого & UD0900307 & Україна & Ворскла \\
\hline протеїну в кормовій масі, & UD0900053 & Болгарія & \\
\hline$\%$ & UD0900023 & Росія & Дробинка \\
\hline & UD0900123 & Росія & Орловська 88 \\
\hline & UD0900452 & Україна & Добір 332/2 \\
\hline & UD0900164 & Португалія & \\
\hline Стійкість до ураження & UD0900057 & Португалія & \\
\hline кореневої системи рослин & UD0900018 & Україна & Вінницька 30 \\
\hline фузаріозом, \% & UD0900164 & Португалія & \\
\hline & UD0900125 & Росія & Орловська 91 \\
\hline & UD0900167 & Україна & Ізида \\
\hline & UD0900017 & Росія & Зазерська \\
\hline & UD0900072 & Україна & Гібридна 13 \\
\hline
\end{tabular}

Два зразки колекції (зразки власної селекції) зареєстровані у Національному центрі генетичних ресурсів рослин України (НЦГРРУ) з видачею свідоцтва: UD0900306 Наталі, Свідоцтво № 389, видане 04.02.2008, UD0900307 Ворскла, Свідоцтво № 595, видане 16.11.2009.

Серед зразків колекції зустрічаються форми досить цікаві за проявом окремих ознак. Так, у зразка UD0900215 (Toplesa) нижній біб розміщений на висоті 89 см, а висота його рослин становить близько 90-98 см, тобто майже всі боби сконцентровані у верхній частині пагонів. До того ж у рослин, боби яких знаходяться на верхівках пагонів, досить короткі міжвузля, майже не помітні, а тому складається враження, що в одному вузлі нараховується 4-5-6 бобів. У зразка UD0900003 Багатоплідна у $95 \%$ рослин по 3-4 боби в одному вузлі.

За кількістю насіння виділилися зразки UD0900072 Гібридна 13, UD0900167 Ізида. 
За масою 1000 насінин, яка досягає 75-80 г, UD0900028 Білоцерківська 34, UD0900168 Білоцерківська 10, UD0900434 Мила. Мілке ж насіння мають зразки UD0900068 M-1, UD0900059 (48-50 г).

Зразки колекції також були оцінені за вмістом протеїну у кормовій масі та за стійкістю до фузаріозних кореневих гнилей. У результаті можна констатувати той факт, що лише досить незначна кількість зразків виявилася толерантною до фузаріозних кореневих гнилей (табл. 1), у більшості зразків рослини значно страждали від даної хвороби.

Звичайно, однорічні бобові культури, в т. ч. і вика, мають досить короткий вегетаційний період і фіксують менше азоту, ніж багаторічні, значна частина його використовується на формування урожаю, але в нормальних умовах $1 / 2-3 / 4$ свої потреби в азоті бобові задовольняють за рахунок симбіонта, зберігаючи запаси азоту в грунті для наступних культур. Однак можливості рослин до біологічної фіксації азоту використовуються неповно. Це пов'язано з недостатньою вивченістю багатьох кормових бобових культур, недоліками технологій вирощування, відсутністю достатньої кількості сортів бобових культур із підвищеною здатністю до біологічної фіксації азоту. Наявність високого азотфіксуючого потенціалу бобових рослин, зокрема, вики ярої, ставить завдання більш повного його використання в рослинництві. Поєднання селекційного процесу бобових культур (у даному разі - вики ярої) з вивченням можливості використання взаємодії макро- та мікросимбіонтів, дало б можливість отримувати і передавати у виробництво сорт бобової культури 3 попередньо підібраним найбільш ефективним штамом симбіонтів.

Сортові особливості азотфіксації самозапильних культур можуть мати досить суттєвий прояв. У рамках різнобічного вивчення зразків колекції та ведення селекційного процесу проводилося також дослідження взаємодії колекційних зразків вики ярої з окремими селекційними штамами бульбочкових бактерій. Вивчалася реакція на інокуляцію бульбочковими бактеріями зразків колекції Гібридна 97, Гібридна 85, Білоцерківська 623 та Наталі. Робота мала на меті спробу поєднання селекційного процесу бобових культур (у даному разі - вики ярої) з вивченням можливості використання взаємодії макро- та мікросимбіонтів, яке б дало не тільки підвищення збору білку, а й зменшило загрозу ураження рослин кореневими гнилями та необхідність використовувати протруйники, що могло б стати одним 3 елементів біологізації системи землеробства. Використання такого способу імунізації рослин дало б змогу без застосування хімічних засобів захисту підвищити неспецифічний імунітет, попередити поширення хвороб, викликаних грунтовими патогенами, й одночасно поліпшити азотне живлення рослин. До того ж у такому разі попереджається забруднення навколишнього середовища ксенобіотиками та зберігається природна грунтова мікрофлора. Крім того зменшення ураження рослин кореневими гнилями, оздоровлення кореневої системи - шлях до підвищення ефективності азотфіксації.

У ході вивчення взаємовідносин бобових кормових рослин і бульбочкових бактерій виявлено суттєвий вплив вдалого підбору штамів симбіотичних азотфіксаторів на розвиток, продуктивність та якість рослин вики, їх вегетативної маси і насіння. У процесі досліджень була структурована роль основних діючих чинників у формуванні окремих ознак продуктивності.

Безперечним є пріоритет факторів зовнішнього середовища, передусім - рівня вологозабезпеченості. Серед факторів, що можуть бути скоректовані, найбільш значний вплив справляє активність штаму-азотфіксатора, сорто-штамова взаємодія та її прояв за даного рівня зволоження (табл. 2).

\section{2. Вплив різних факторів на розвиток рослин ярої вики}

\begin{tabular}{|c|c|c|c|c|c|c|}
\hline \multirow{2}{*}{ Фактори } & \multicolumn{5}{c|}{ Показники розвитку рослин } \\
\cline { 2 - 7 } & \multicolumn{2}{|c|}{ висота } & $\begin{array}{c}\text { кількість генеративних } \\
\text { органів }\end{array}$ & \multicolumn{2}{c|}{ маса рослин } \\
\cline { 2 - 7 } & $\mathrm{mS}$ & ранг & $\mathrm{mS}$ & ранг & $\mathrm{mS}$ & ранг \\
\hline Сорт (А) & 22,15 & 7 & 6,00 & 5 & 35,65 & 4 \\
\hline Штам (В) & 57,54 & 6 & 7,97 & 3 & 17,18 & 5 \\
\hline Умови зволоження - рік (C) & 30681,88 & 1 & 135,93 & 1 & 253,45 & 1 \\
\hline А х В & 206,56 & 2 & 2,09 & 6 & 11,80 & 7 \\
\hline А х С & 120,41 & 4 & 7,93 & 4 & 35,86 & 2 \\
\hline В х С & 197,4 & 3 & 9,7 & 2 & 3,85 & 3 \\
\hline А х В х С & 71,91 & 5 & 0,75 & 7 & 5,35 & 6 \\
\hline
\end{tabular}


СІЛЬСЬКЕ ГОСПОДАРСТВО. РОСЛИННИЦТВО

3. Урожай зеленої маси зразка Наталі по окремих варіантах використання штамів бульбочкових бактерій (2004-2005 pp.), џ/га

\begin{tabular}{|c|c|c|c|}
\hline \multirow{2}{*}{ Штам (варіант) } & \multicolumn{3}{|c|}{ Роки } \\
\cline { 2 - 4 } & 2004 & 2005 & Середнє за 2 роки \\
\hline Контроль & 477 & 375 & 426 \\
\hline 4 & 527 & 364 & 445 \\
\hline 6 & 486 & 258 & 372 \\
\hline 30 & 494 & 280 & 387 \\
\hline 32 & 508 & 394 & 451 \\
\hline 0616 & 499 & 400 & 449 \\
\hline 142 & 472 & 391 & 430 \\
\hline $\mathrm{HIP}_{005}$ & 0,20 & 0,15 & - \\
\hline
\end{tabular}

4. Урожай насіння) зразка Наталі по окремих варіантах використання штамів бульбочкових бактерій (2005 р.)

\begin{tabular}{|c|c|}
\hline Штам (варіант) & Урожай насіння, ц/га \\
\hline Контроль & 13,70 \\
\hline 0616 & 14,25 \\
\hline 142 & 16,95 \\
\hline 32 & 14,84 \\
\hline 2 & 13,50 \\
\hline
\end{tabular}

Від комплементарності сорту і штаму найбільше залежить висота рослин, а, відповідно, й тісно корелюючий із цим показником урожай зеленої маси - основна господарсько цінна ознака кормової культури (табл. 2). Отже, в цьому напрямі можлива ефективна селекційна робота. На кількість генеративних органів (а отже, й на урожай насіння) найбільше впливає активність штаму та ії прояв у певних умовах зволоження.

Базуючись на отриманих даних, наступні до-

\section{БІБЛІОГРАФІЯ}

1. Демиденко Р. Б. Сравнительная характеристика зернобобовых культур при возделывании их на корм в зоне серых лесных почв//Однолетние бобовые культуры. - М. : Колос, 1971. - С. 41-48.

2. Кириченко В. В., Рябчун В. К., Богуславський Р. Л. Роль генетичних ресурсів рослин у виконанні державних програм // Генетичні ресурси рослин. - №5. - 2008. - С. 7-13.

3. Колесник И. В. Поражаемость вики корневыми гнилями фузариозного типа и изучение влияния на нее сортовых особенностей симбиотической азотфиксации у перспективных селекционных образцов.// Материалы V Международной научно-практической конференции «Селекция, экология, технология возделывания и переработки нетрадиционных растений». - г. Алушта, Симферополь, 1996. - С. 149.

4. Колесник И. В. Комплементарность генотипов макро- и микросимбионтов как возможный фактор формирования устойчивости вики посевной слідження мали за мету підбір комплементарних штамів мікросимбіонтів до перспективного селекційного матеріалу. Зокрема, при інокуляції насіння зразка Наталі набором штамів бульбочкових бактерій протягом 2004-2005 рр. було виділено ті, що найбільше підвищили врожай зеленої маси (табл. 3), а окремі з них істотно вплинули на врожай насіння цього зразка в 2005 p. (табл. 4).

Висновки. Таким чином, в процесі вивчення взаємодії зразків колекції вики ярої з активними штамами бульбочкових бактерій до них (сорти селекції ПДСГДС ім. М. І. Вавилова) були попередньо підібрані достатньо придатні за комплементарністю штами бульбочкових бактерій, структурована роль діючих чинників у формуванні складових урожаю та окреслені можливості використання взаємодії макро- і мікросимбіонтів як одного $з$ елементів у створенні цілісної системи біологічного землеробства.

к корневым гнилям фузариозного типа. // Материалы 7-й Международной научно-практической конференции «Нетрадиционное растениеводство, экология и здоровье». - Симферополь, 1998. C. 240-241.

5. Колісник I. В. Перспективи спорідненої селекціi ярої вики та бульбочкових бактерій // Корми і кормовиробництво. - № 47. - К. : Аграрна наука, 2001. - C. 76-77.

6. Колісник А. В., Колісник І. В., Федосієнко Д. В. [ma ін.]. Економіко-технологічні аспекти біологічної азотфіксації в екологічному рослинництві // Екологізація економіки та освіти як чинник сталого розвитку суспільства. Науковий вісник НЛТУ України. - Вип. 15.6. - Львів. - 2005. C. 488-490.

7. Шумилин П. И., Куляева Н. А. Кормовые достоинства зернобобовых культур при возделывании их на серых лесных почвах // Однолетние бобовые культуры. - М. : Колос, 1971. - С. 80-85. 